Red Cross, and brought together the delegates of fifty National Societies at meetings that lasted until 12 October.

Every day, one or two papers were presented, followed by round table discussions during which participants gave their views on the hopes and wishes of the younger generation under the sign of the red cross, the red crescent and the red lion and sun, on all that our movement is able to offer them, and on how to take a more active share in humanitarian work.

\title{
THE EMPRESS SHÔKEN FUND
}

In 1963, the year of the Red Cross centenary, the Empress of Japan increased the Shôken Fund by a donation of 3,600,000 yen. The International Review published an article at the time in which it described the noble figure of the Empress Shoken (1850-1914), illustrated by a picture showing her on a visit to the Hiroshima military hospital, accompanied by the Emperor. ${ }^{1}$

Following the recent visit of the Japanese sovereigns to the ICRC and the further generous contribution made by the Japanese Government to the Empress Shôken Fund, we wish to remind our readers of the meaning of this inalienable Fund.

"Shôken", which means "lively and sparkling", was the posthumous title bestowed on the Empress Haruko, wife of the Emperor Meiji, as a tribute to the qualities of her heart and mind. While renowned for her beauty and for the poetry she wrote, the Empress was still more noted for her goodness. She helped a great many philanthropic institutions and was also a patron of the Japanese Red Cross, founded in 1887. From the first, she and the Emperor took an interest in the development of humanitarian law. Thus Japan signed the 1864 Geneva Convention barely two years after the International Conference which had recommended its adoption.

\footnotetext{
${ }^{1}$ See International Review, October 1963.
} 
In 1912, the Empress Shôken decided to establish a fund, with a capital of one hundred thousand gold yen, designed to promote Red Cross relief work at international level. The donation was announced by the Japanese delegate to the Ninth International Conference of the Red Cross, meeting in Washington. The gathering was asked to provide the Fund with appropriate statutes, and it was decided to entrust the Fund to the ICRC in Geneva.

The first world war laid heavy tasks on the Red Cross, and it was not until 1921 that the Tenth International Conference, which was held in Geneva, succeeded in making an initial distribution out of the Empress Shôken Fund to enable five National Societies to carry out an urgent project. The sum they were allocated (Sw.Fr. 140,000) was exceptionally large owing to the fact that the war had prevented allocations.

The regulations for the Empress Shôken Fund were amended in 1934, in order that the League of Red Cross Societies, which had been established in 1919, might be associated with the ICRC in decisions relating to the allocation of revenues. Since then the Fund has been administered by a Joint Commission composed of three members from each institution.

This year, the Empress Shôken Fund has attained a capital of Sw.Fr. 1,977,067. The Joint Commission, which is presided over by Mr. R. Gallopin, a member of the ICRC, has distributed a total sum of Sw.Fr. 83,108 to five National Red Cross Societies in Africa, Latin America and Asia, to help them improve their equipment and develop their blood transfusion and emergency relief activities. ${ }^{1}$

On the occasion of the visit of Their Majesties the Emperor and Empress of Japan to ICRC headquarters, the Japanese Government decided to increase its contribution to the Empress Shôken Fund, under a further five-year programme following the 1966-1970 programme.

1 Plate. 